\title{
PEMANFAATAN LIMBAH PLASTIK SEBAGAI ALTERNATIF BAHAN PELAPIS (UPHOLSTERY) PADA PRODUK INTERIOR
}

\author{
Yunida Sofiana \\ Jurusan Desain Interior, Fakultas Komunikasi dan Multimedia, Bina Nusantara University, \\ Jln. K.H. Syahdan No. 9 Palmerah, Jakarta Barat 11480 \\ ysofiana@binus.edu
}

\begin{abstract}
Environment pollution which is caused by garbage, especially plastic products, is one undeniable thing nowadays. Environment pollution by non-degradable materials could be decreased in 3Rs that are recycling, reusing, reducing. Recycle method is one of creative methods; the plastic waste could be recycled into matting materials that substitute natural material (pandanus) and also to be alternative upholstery in interior products. Plastic waste treatment process until disposable is easier than natural material which has to go through several stages like drying and staining. What could be gained from pandanus could also be gained from plastic waste, so there are many things probable products could be designed. The product image is assumed to be modern, one trend nowadays.
\end{abstract}

Keywords: plastic waste, recycling, design strategy, material

\begin{abstract}
ABSTRAK
Pencemaran lingkungan yang disebabkan oleh sampah terutama plastik adalah hal yang tidak bisa dihindari lagi saat ini. Pencemaran oleh bahan yang tidak dapat terdegradasi oleh alam tersebut dapat dikurangi dengan cara $3 R$ yaitu mendaur ulang (recycle), menggunakan kembali (reuse), dan mengurangi pemakaiannya (reduce). Metode daur ulang adalah salah satu metode kreatif. Limbah plastik tersebut dapat didaur ulang menjadi bahan baku anyaman pengganti material alam (pandan) dan juga dapat dijadikan alternatif bahan pelapis atau upholstery pada produk interior. Proses pengolahan limbah plastik hingga siap pakai juga lebih mudah dilakukan dibandingkan bahan baku alam yang melalui banyak tahapan seperti proses pengeringan dan pewarnaan. Apa yang bisa dibuat dari material alam seperti pandan, tentunya bisa dibuat dari limbah plastik, sehingga banyak sekali kemungkinan produk yang bisa didesain dari bahan limbah plastik tersebut. Image produk yang dihasilkan juga berkesan modern, yang merupakan tren yang cukup digemari saat ini.
\end{abstract}

Kata kunci: limbah plastik, daur ulang, strategi desain, bahan baku 


\section{PENDAHULUAN}

Plastik secara bertahap sudah mulai menggantikan bahan material lain seperti kayu, besi, kertas, kain, kulit, dan lain-lain. Hal ini dapat dilihat dari banyaknya jenis barang yang diproduksi menggunakan plastik sebagai bahan dasarnya, dari mainan anak-anak, perabotan rumah tangga, elektronik, kemasan produk dan masih banyak lagi. Tidak ada jenis barang yang luput dari pemakaiannya, termasuk produk interior seperti kursi, meja, dan aksesori rumah. Salah satu penyebabnya karena plastik memiliki banyak kelebihan dibandingkan material lain yaitu kuat, tekstur mengkilat, licin, anti air,anti karat, tahan terhadap bahan kimia, lentur dan fleksible, dan juga biaya produksi yang relatif murah.

Sayangnya, plastik bukanlah material yang sempurna, plastik juga memiliki kelemahan yang cukup fatal dilihat dari sisi lingkungan yaitu hampir separuh jenis plastik yang dihasilkan oleh industri tidak dapat terurai dengan mudahnya di alam. Dan ada beberapa jenis plastik yang tidak bisa di lebur atau dihancurkan. Sehingga plastik yang tidak dapat dilebur tersebut akan dibuang dan menumpuk menjadi gunungan sampah yang akan terus bertambah seiring bertambahnya pemakaian. Lambat laun sampah plastik yang tidak dapat dilebur atau dihancurkan akan menjadi limbah yang apabila dibiarkan akan menjadi polusi bagi lingkungan.

Dari data KLH 2007 dalam Greenpress Network (2009) menunjukkan, volume timbunan sampah di 194 kabupaten dan kota di Indonesia mencapai 666 juta liter atau setara 42 juta kilogram, dimana komposisi sampah plastik mencapai 14 persen atau enam juta ton. Dari data ini bisa dilihat bahwa, apabila limbah sampah ini tidak dapat dikurangi maka akan berdampak negatif bagi lingkungan dan juga alam.

Dengan kesadaran tersebut, dilakukan beberapa cara untuk mengurangi limbah plastik yang makin banyak jumlahnya, diantaranya dengan melakukan metode 3R yaitu Reuse, Reduce, dan Recycle. Metode ini sudah banyak dilakukan oleh beberapa industri, lembaga swadaya dan individu yang peduli lingkungan untuk membantu mengurangi dampak limbah plastik bagi lingkungan. Dari ketiga metode tersebut, metode yang dinilai cukup efektif dalam mengurangi dampak limbah plastik adalah metode recycle (daur ulang).

Metode daur ulang merupakan proses menjadikan suatu bahan bekas menjadi bahan baru dengan tujuan mencegah adanya sampah. Dengan melakukan proses daur ulang ini, diharapkan limbah plastik dapat dimanfaatkan menjadi bahan yang dapat digunakan kembali dan dapat membantu mengurangi limbah yang ada. Metode daur ulang juga dapat menghemat sumber daya alam dan mengurangi ketergantungan terhadap bahan baku tertentu.

\section{METODE PENELITIAN}

Metode penelitian yang digunakan adalah melakukan pengamatan (observation research) dan studi pustaka. Pengamatan yang dilakukan terkait dengan potensi limbah plastik dan karakteristik dari jenis plastik yang ada. Dilanjutkan dengan pengamatan bagaimana limbah plastik di proses dan produk apa saja yang dapat dihasilkan dari limbah tersebut. Metode penelitian dilanjutkan dengan studi pustaka yang berkaitan dengan plastik dan permasalahannya dari buku, artikel koran dan internet. Sumber informasi diseleksi dan dianalisis untuk mendapatkan simpulan. Data dari hasil pengamatan dan studi pustaka diolah secara kualitatif. 


\section{HASIL DAN PEMBAHASAN}

\section{Jenis Plastik}

Menurut Lambert \& Halliwell (2004) plastik digolongkan menjadi 2 jenis yaitu: termoplastik dan thermosetting (penyetel suhu). Ketiga jenis ini memiliki struktur dan karakteristik yang berbedabeda. Termoplastik merupakan jenis plastik yang umumnya digunakan untuk kemasan bahan baku dengan type LDPE, PP dan ACETATE. Karakteristik dari termoplastik dapat dibentuk kembali dengan mudah dan diproses menjadi bentuk lain, ringan, hemat energi serta murah. Sedangkan jenis thermosetting, bila telah mengeras tidak dapat dilunakkan kembali. Plastik yang paling umum digunakan dalam kehidupan sehari-hari adalah dalam bentuk termoplastik.

Plastik merupakan bahan elastomer yang secara komersial digunakan oleh masyarakat dan industri untuk membuat barang-barang, bungkus atau kemasan dari suatu komoditas, dan lain-lain. Berbagai industri plastik berlomba-lomba memciptakan jenis plastik baru yang disesuaikan dengan kegunaannya. Seperti industri makanan dan minuman instan yang memproduksi dan menggunakan plastik berlapis alumunium foil atau plastik multilayer sebagai kemasan karena dianggap aman dan dapat menjaga produk tetap higienis. Plastik kemasan berlapis alumunium foil menggantikan penggunaan kaca, kaleng dan kertas sebagai bahan baku pengemas. Namun demikian plastik tetaplah bahan baku utama yang digunakan.

Demikian luasnya penggunaan plastik membuatnya sangat sulit dibedakan antara jenis yang satu dengan yang lain. Masing-masing plastik memiliki karakter dan penggunaan yang berbeda-beda. Setiap plastik memiliki kode-kode yang akan membedakan kegunaannya. Kode-kode tersebut memudahkan pengguna untuk melihat karekter plastik yang digunakan, sehingga untuk mendaurulangnya pun dapat dilihat dari kode yang ada di setiap plastik. Untuk mengetahui jenis plastik yang digunakan sebagai material dasar sebuah produk, dapat dilihat dari kode yang tercetak pada plastik. Kode tersebut berupa angka dari 1-7. Penjelasannya adalah sebagai berikut:

Plastik dengan kode 1 yaitu PET/PETE dikenal dengan nama Polyethylene telephtalate. Jenis plastik ini banyak digunakan untuk botol minuman seperti botol air mineral, botol jus. Botol dari jenis ini hanya direkomendasikan untuk satu kali pemakaian. Penggunaannya sebagai bahan dasar botol kemasan mencapai 30\% pemakaian dunia. Selain itu juga digunakan sebagai serat sintetis atau poliester yang mencapai $60 \%$ pemakaian dunia. Karekteristik dari jenis plastik ini adalah berwarna jernih, transparan atau tembus pandang, liat, kuat, dan tahan panas. Dimensinya stabil, tidak beracun dan dapat didaur ulang kembali menjadi pakaian, tas, furnitur, karpet.

Plastik dengan kode 2 HDPE atau Polyethylene densitas tinggi. Merupakan plastik serba guna yang dapat didaur ulang. Dapat didaur ulang menjadi botol, keramik, pipa dan outdoor furniture. Biasanya digunakan untuk botol susu warna putih, Tupperware, galon air minum, dan kursi lipat. Sifat bahannya lebih kuat, buram, tahan terhadap suhu tinggi dan mudah diproses dan dibentuk. Karena kekuatannya, plastik jenis ini aman digunakan. Plastik dengan kode 3 yaitu PVC atau Polyvinyl chloride. Merupakan jenis plastik yang paling sulit didaur ulang. Ditemukan pada plastik pembungkus (cling wrap), botol detergen, dan bahan spanduk dari vinyl. Sifat dari plastik ini serbaguna, mudah dicampur, kuat, tahan minyak, tahan kimia, dan jernih.

Plastik dengan kode 4 adalah LDPE atau Polyethylene densitas rendah. Merupakan plastik yang terbuat dari minyak bumi, dengan tipe plastik coklat (termoplastik). Biasa digunakan utuk tempat makanan, plastik kemasan dan botol yang lembek. Sifat mekanis dari plastik ini adalah kuat, agak tembus pandang, fleksibel, tahan panas, kimia dan permukaan agak berlemak. Jenis plastik ini dapat didaur ulang, baik untuk barang-barang yang memerlukan fleksibilitas tetapi kuat dan memiliki resistensi yang baik terhadap reaksi kimia. Plastik jenis ini sulit di hancurkan, tetapi baik digunakan sebagai tempat makanan. 
Plastik dengan kode 5 adalah PP atau Polypropylene. Memiliki ciri-ciri transparan yang tidak jernih atau berawan, lebih kuat, ringan dengan daya tahan tembus uap yang rendah. Memiliki ketahanan yang baik terhadap lemak, stabil terhadap suhu tinggi dan cukup mengkilat. Ditemukan dalam tutup botol, botol makanan, sedotan. Memiliki titik lebur yang tinggi dan dapat digunakan untuk tempat cairan panas. Polypropylene merupakan bahan plastik terbaik untuk tempat makanan, minuman dan sebagai tempat menyimpan makanan, botol minum dan botol bayi.

Plastik dengan kode 6 adalah PS atau Polystyrene. Dikenal dengan nama komersial styrofoam (gabus sintetis). Jenis plastik ini dikhawatirkan dapat melepaskan toksin ke dalam makanan. Memiliki sifat serba guna, jernih, mudah dibentuk menjadi foam. Dapat didaur ulang dan digunakan untuk membuat insulasi. Plastik dengan kode 7 adalah Policarbonate. Merupakan jenis plastik selain plastik bersimbol 1-6. Jenis plastik ini banyak digunakan untuk DVD, kacamata hitam, anti peluru, gallon air 5 liter. Memiliki sifat beragam, tergantung kombinasi bahan baku penyusun. Jenis plastik ini tidak mudah untuk didaur ulang, namun bisa dilakukan.

\section{Potensi Limbah Plastik}

Melimpahnya limbah plastik merupakan potensi yang sangat besar apabila bisa dapat di daur ulang menjadi alternatif bahan baku pengganti bahan baku alam. Limbah plastik tersebut dapat dikreasikan menjadi bahan baku atau pelapis (upholstery) tanpa harus melalui peleburan terlebih dahulu. Proses ini lebih mudah dan murah dibandingkan melebur plastik dengan bahan tambahan (aditif). Proses daur ulang limbah plastik menjadi bahan baku pelapis (upholstery) dilakukan dengan mengolah limbah plastik dengan beberapa cara, yaitu dengan menggabungkan lembaran-lembaran plastik menjadi bahan dasar, baik dengan menjahitnya atau menempelkannya pada bahan baku lain. Hasilnya berupa lembaran-lembaran atau panel, dan siap diaplikasikan ke produk yang telah didesain.

Cara lain yang dapat dilakukan untuk proses daur ulang limbah plastik menjadi alternatif bahan baku anyaman adalah dengan memotong-motong lembaran plastik menjadi lembaran kecil panjang, dan menganyamnya, lalu mengaplikasikannya kepada produk yang telah didesain. Lembaran dan anyaman plastik dapat juga digunakan sebagai bahan baku pelapis atau upholstery untuk kursi, bantal kursi, kursi puff, tempat sampah, boks, dan lain-lain.

Plastik hasil daur ulang memiliki beberapa kelebihan, antara lain: (1) memiliki kekuatan, karena plastik ini baru dapat terurai sempurna dalam waktu 80 sampai 300 tahun sehingga kekuatan tidak diragukan lagi; (2) plastik juga anti air, karena dirancang untuk melindungi produk yang ada di dalamnya dari udara dan air; (3) memiliki desain dan warna yang menarik. Kemasan plastik di desain untuk menarik perhatian konsumen dengan warna warna yang menarik; (4) murah, kebanyakan plastik kemasan digunakan sebagai pembungkus atau kemasan sekali pakai, sehingga akan dibuang apabila tidak digunakan lagi. Limbah plastik kemasan ini dapat diperoleh secara gratis apabila memiliki strategi dalam pengumpulannya; (5) lentur dan fleksibel. Plastik adalah material yang mudah dibentuk dan dilipat. Dengan sifatnya ini dapat dimanfaatkan karena memiliki sifat yang sama dengan kain dan kertas.

\section{Proses Pengolahan Limbah Plastik}

Menurut Syafitrie dalam Macklin (2009), limbah plastik dapat di daur ulang kembali menjadi barang plastik, tetapi hanya $80 \%$ jenis plastik yang dapat diproses dengan melakukan teknik pencampuran dengan bahan baku baru dan additive untuk meningkatkan kualitasnya. Tetapi untuk sisanya tetap sulit untuk di daur ulang, walaupun memungkinkan, tetapi membutuhkan biaya yang besar serta proses yang lebih panjang. Untuk melakukan proses daur ulang plastik, ada tahapantahapan yang harus dilakukan: 
Tahap pertama adalah melakukan pemisahan limbah plastik dari kotoran, zat kimia maupun limbah lainnya seperti limbah organik, lalu dikelompokkan dengan plastik yang sejenis. Pemisahan ini dapat dilakukan secara manual. Metode pemisahan secara manual ini merupakan metode sederhana yang cukup mudah dilakukan, dan murah biayanya. Hal ini sangat dimungkinkan karena pemisahan secara manual dapat dilakukan di Indonesia yang mempunyai tenaga kerja melimpah sehingga pemisahan tidak perlu dilakukan dengan peralatan canggih seperti yang dilakukan oleh negara maju, karena memerlukan biaya tinggi. Kondisi ini memungkinkan berkembangnya industri daur ulang plastik di Indonesia.

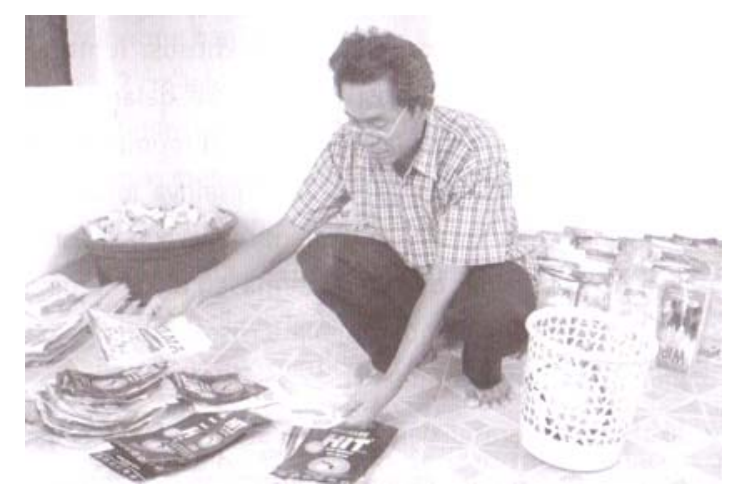

Gambar 1 Pemisahan limbah plastik

Tahap kedua adalah melakukan pencucian. Di tahap ini, limbah yang telah dipisahkan, dibersihkan dan dicuci untuk dihilangkan zat zat kimia dan kotoran yang melekat. Kemudian dikeringkan dengan lap.

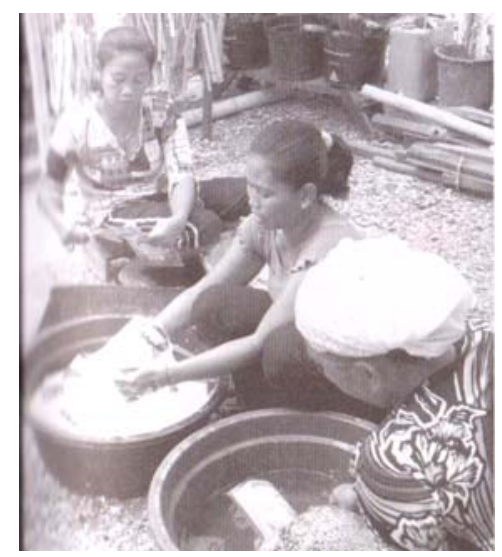

Gambar 2 Pembersihan limbah plastic

Tahap terakhir dari proses pengolahan limbah ini adalah pemotongan plastik yang telah dibersihkan. Pada tahap ini, plastik sudah siap diolah dan masuk pada proses produksi. Sebelum plastik di potong potong, desain dari produk yang akan dibuat sudah disiapkan. Artinya, potongan plastik tersebut nantinya disesuaikan dengan desain yang akan dibuat. Potongan plastik memiliki panjang dan ketebalan yang bervariasi sesuai kebutuhan desain dan produk yang akan dibuat. 


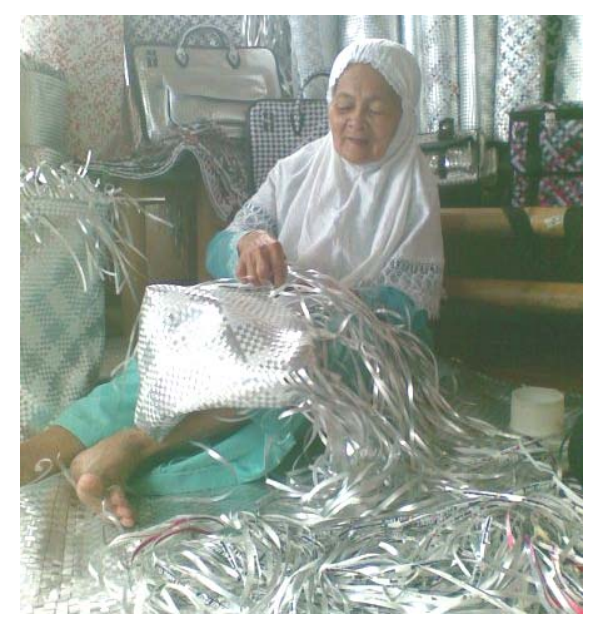

Gambar 3 Pengolahan Limbah plastik

\section{Strategi Desain Produk}

Menurut Oborne (1982) untuk menghasilkan produk yang baik dan berkualitas, segi pemenuhan fungsi dan bentuk selalu terkait erat dengan pemilihan bahan serta proses pembuatannya. Pengetahuan mengenai karakteristik bahan dan proses pembuatannya sangat menentukan keberhasilan suatu produk. Sebelum memulai proses desain terhadap suatu produk perlu dilakukan strategi desain terkait dengan produk yang akan dibuat. Strategi yang perlu diperhatikan berkaitan dengan bahan yang digunakan, konstruksi dari produknya, proses pembuatannya, biaya produksi yang dikeluarkan dan kualitas produk yang akan dihasilkan.

Strategi desain yang dapat dilakukan designer dalam hal ini adalah dengan melakukan pola penelusuran mencari metode baru yang bisa mendapatkan solusi yang terbaik dari produk yang ada karena produk yang lama sudah tidak memadai lagi atau tidak sesuai dengan situasi masa kini. Cara yang dilakukan dengan mendesain produk baru yang lebih baik dari segi kegunaan, desain, dan harga. Strategi desain lain yang dapat dilakukan adalah dengan mengaplikasikan material limbah plastik sebagai material upholstery atau pelapis untuk produk desain yang telah ada. Pengaplikasian ini akan membedakan 2 produk yang sama dengan menggunakan bahan baku yang berbeda. Sebagai contoh, kursi puff, ottoman dan bantal kursi yang biasanya dilapis dengan bahan baku kain (fabric) dan kulit (leather) dapat diganti dengan bahan baku limbah plastik (Gambar 4-6).

\section{Produk Hasil Limbah}

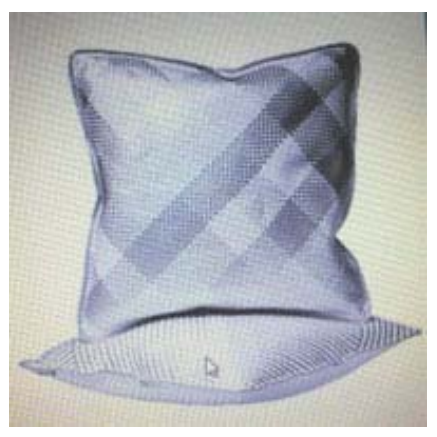

Gambar 4 Bantal kursi (dyrt design product)

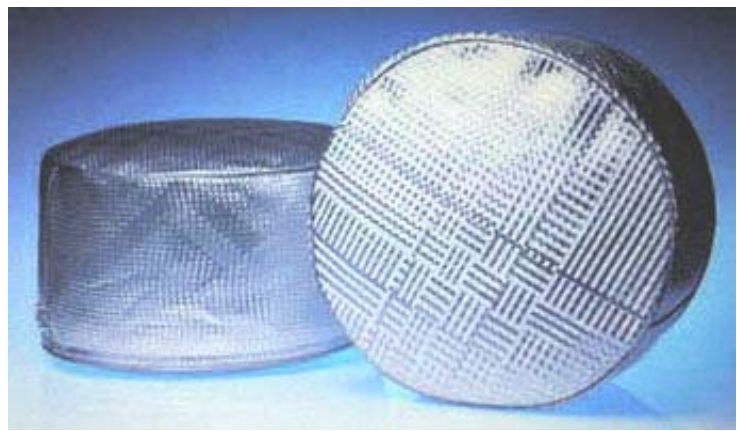

Gambar 5 Ottoman (dyrt design product) 


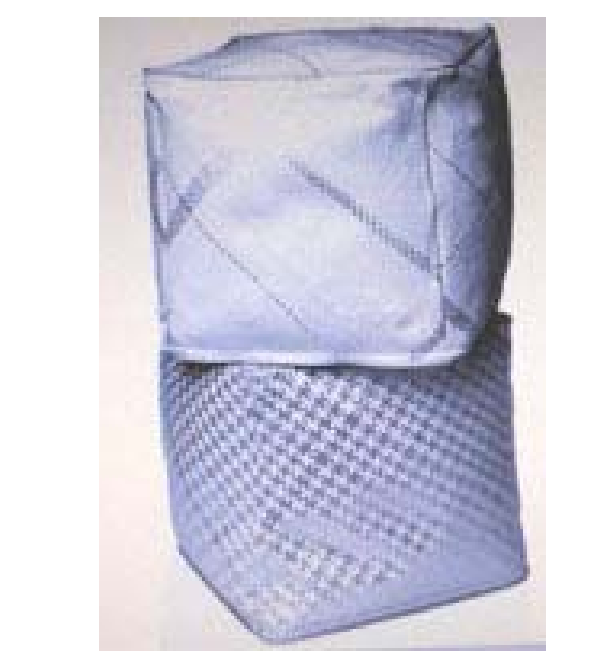

Gambar 6 Kursi puff (dyrt design product)

\section{SIMPULAN}

Dapat disimpulkan bahwa limbah plastik masih memiliki potensi yang sangat besar. Banyak produk yang telah dimanfaatkan dari limbah plastik tersebut seperti tas dan peralatan rumah tangga. Tapi belum banyak yang memanfaatkannya sebagai bahan baku yang dapat digunakan didalam mendesain suatu produk, khususnya produk interior, sedangkan karakteristik dari bahan baku limbah plastik sangat sesuai digunakan pada produk interior yang membutuhkan kekuatan, fleksibilitas dan berkesan modern. Kendala yang dihadapi adalah belum banyaknya pengrajin yang mau memanfaatkan limbah plastik untuk produk interior. Hal ini dikarenakan belum adanya konsep produk yang jelas, sehingga pemanfaatan limbah plastik terkesan belum maksimal. Peran serta desainer dalam proses pemanfaatan limbah plastik ini sangat diharapkan untuk dapat meningkatkan kualitas barang yang dihasilkan oleh pengrajin dan jenis barang yang dihasilkan akan lebih beragam. Desainer dapat memberikan masukan berupa ide dan saran dalam pengembangan produk, sehingga produk yang dihasilkan berkualitas. Diharapkan produk interior di masa yang akan datang akan lebih ramah lingkungan dan dapat memanfaatkan bahan daur ulang dalam setiap desainnya.

\section{DAFTAR PUSTAKA}

Greenpress Network. (2009, Mei 5). KLH akan Hitung Cepat Data Sampah. Greenpress Network, dari http://greenpressnetwork.blogspot.com/2009/05/klh-akan-hitung-cepat-data-sampah.html

Lambert, B., \& Halliwell, J. (2004). Revise for Product Design: Resistant Materials Technology. UK: Heinemann.

Macklin, B. (2009, Januari 20). Pengolahan Limbah Plastik Dengan Metode Daur Ulang (Recycle), dari http://onlinebuku.com/2009/01/20/pengolahan-limbah-plastik-dengan-metode-daur-ulangrecycle/ 